2014-10-01

The Experience of Care leavers in UK Higher Education

\title{
Cotton, Debby
}

http://hdl.handle.net/10026.1/4369

10.5456/wpll.16.3.5

Widening Participation and Lifelong Learning

The Open University

All content in PEARL is protected by copyright law. Author manuscripts are made available in accordance with publisher policies. Please cite only the published version using the details provided on the item record or document. In the absence of an open licence (e.g. Creative Commons), permissions for further reuse of content should be sought from the publisher or author. 


\title{
The Experience of Care leavers in UK Higher Education
}

\author{
Debby R. E. Cotton \\ Plymouth University, UK \\ Email: dcotton@plymouth.ac.uk \\ Patricia Nash \\ Plymouth University, UK \\ Email:pnash@plymouth.ac.uk \\ Pauline E Kneale \\ Plymouth University, UK \\ Email: Pauline.kneale@plymouth.ac.uk
}

\begin{abstract}
This paper reports the findings of a qualitative study into the experience of care leavers (students who have previously been in local authority care) at a UK university. Working with a small group of final year care leaver students, the research used a narrative interview approach to explore their experiences throughout their time in Higher Education (HE), and their future plans after completion. Analysing the interviews using a resilience framework, the findings illustrate a range of risk and protective factors which impact on success in higher education (HE) for this group of students. Like other non-traditional students, key factors include motivation for participation, good preparation for university life and learning, and academic, personal and financial support. Particularly important for this group is the availability of a safety net, and support from a significant adult. This was often provided by the university care leavers' service which offered a crucial source of support for students without another obvious point of contact. Perhaps surprisingly, all students felt that being in care had had a positive impact on their university experience although for varying reasons. All of the students in the study went on to complete their degrees successfully despite the challenges encountered.
\end{abstract}

Key terms: care leavers; non-traditional students; widening participation; student support; resilience.

\section{Introduction}

Young people leaving local authority care are one of the most underrepresented groups in higher education $(\mathrm{HE})^{1}$, and they often struggle to cope financially and emotionally unless they are provided with significant

1 The Children (Leaving Care) Act 2000 in the UK states that a Care Leaver is someone who has been in the care of the Local Authority (local government) for a period of 13 weeks or more spanning their 16th birthday. 
support (Cheung and Heath, 1994). Extant research shows that children in care have generally poor attainment at all levels of education; however the reasons for this are contested. For some children, the impact of the pre-care experience will be crucial. A history of abuse or neglect, and consequent missed schooling (particularly if combined with low socio-economic status and relative poverty of the birth family), generally impacts negatively on educational attainment, at least in the short term (Berridge, 2007, 2012; Welbourne and Leeson, 2012). However, other researchers point to in-care factors to explain the low attainment of 'looked after' children ${ }^{2}$. Issues identified include the low expectations of teachers and social workers; poor communication between Social Services and Education Services; multiple placements and changes of school; school exclusions and truanting; bullying; and lack of educational encouragement from carers (Jackson et al., 2005; Jackson and Simon, 2006; Cashmore et al., 2007). Arguably, the experiences of young people before and in care are interlinked and both have a profound effect on their entire lives (Dixon et al., 2006, Driscoll, 2011). In the face of these identified educational barriers, it is hardly surprising that few care leavers continue into further or higher education. However, widening participation activities have increasingly enabled access for this group. A recent study by Driscoll (2011) reported that the percentage of care leavers in HE had improved from 5\% in 2004 to $7 \%$ in 2010, although it appears that the level has remained static since then (DfE, 2012). Nonetheless, the proportion of care leavers progressing to HE is tiny compared to non-care leaver entrants (43\%). Whilst, in part, this can be explained by low attainment in secondary education, it seems that other factors such as pre-care experience and the amount of time in care, may limit the number who aspire to access HE (Berridge, 2012).

Despite increasing interest in widening participation, there is a paucity of research on care leavers' experiences in HE. The single large longitudinal study in the UK (Jackson et al., 2005) identified a number of recurring problems including: lack of information and guidance before attending; low expectations and little encouragement from social workers; reluctance by the local authority to provide financial assistance; difficulty in finding accommodation especially during the vacations; inability to meet educational expenses, leading to engagement in extensive paid work; and the absence of social support at university. In addition, personal, social and emotional difficulties resulting from previous life experiences were found to interact with, and impact on, academic success. Care leaver students often took longer to complete their studies than others, needing to repeat assignments, modules or even years of study and approximately $10 \%$ withdrew because of such difficulties. Few universities had specific polices with regard to student care leavers, or provided dedicated support.

2 The expressions 'looked-after children' and 'children in care' are used interchangeably here. 'Looked-after children' is the UK legal term, while 'children in care' is the term that children are more likely to identify with. 
Whilst this research by Jackson et al. (2005) has brought about some positive changes - such as the inclusion of a tick box on the UK university application form to indicate care leaver status, and increased support offered by local authorities and universities - care leavers remain poorly represented in $\mathrm{HE}$ and have a tendency to underperform or drop out (Hyde-Dryden, 2012). Studies of academically-successful care leavers have started to identify aspects of resilience which have enabled these students to overcome difficulties faced ('risk factors'), through having access to so-called 'protective factors' (Stein, 2006, 2008; Driscoll 2011, 2013; Munson, 2013). Examples of protective factors include: strong self-motivation; relationship with a significant adult; stable school experiences; feeling in control; positive identity; supportive social networks; and undertaking extracurricular activities or volunteering (Stein, 2006; Munson, 2013). Conversely Jackson et al. (2005) identified potential areas of stress which could reduce the resilience of care leavers in HE, including: shortage of money; fear of debt; psychological problems arising from care and pre-care experience; difficulty with academic work; relationship difficulties; problems in the birth or foster family; and isolation or lack of emotional support.

For care leavers, accessing and succeeding in education is a significant achievement, and research which identifies the kinds of support which would be most usefully provided by universities is urgently needed. This study, although small-scale, contributes to the emerging research into the experiences of care leaver students by exploring their whole-university experience (as final year students looking back over their university career, as well as looking forward to their potential employment) in the context of a university with a significant number of care leavers. The research uses a resilience framework, and illustrates the ways in which protective and risk factors may influence the degree outcomes of final year care leavers.

\section{Aims of project}

This small scale project aimed to investigate the entire university experience of final year care leavers in order to identify:

- perceived impacts of their care leaver status on their experience,

- difficulties encountered,

- sources of support and the factors which were perceived to have contributed to successful outcomes (completion and attainment).

The researchers aimed to identify protective and risk factors for each of the individual students, both through their pre-care and in-care experiences as well as whilst in HE, and explore the ways in which these impacted on resilience during their time at university, their degree result and subsequent employability. 


\section{Methodology and methods}

The research was undertaken in the context of a new university with a significant cohort of care leaver students. There were 119 known to the university at the time of the research (around $60 \%$ of whom were female), though this is probably an under-estimate due to a reluctance by some applicants to share this information. Owing to the sensitivity of the subject matter and the potential vulnerability of the research participants, as well as the desire for in-depth data on the student experience, a qualitative, interpretive approach was selected as most appropriate. Following ethical clearance, narrative interviews (Mishler, 1986) were undertaken by an independent researcher with experience working with vulnerable groups. The University has a dedicated Care Leaver Service so, for reasons of anonymity and data protection, the Care Leaver Advice Officer contacted care leavers in their final year with information about the research and a consent form. Financial incentives for participation were offered, and there was an opportunity to ask questions prior to agreeing to take part.

Interview questions were flexible and tailored to the context but constructed to cover the following areas: preparation for university; induction/transition; financial aspects including amount of paid work; academic experience including support received; social and personal experience including support received; support from the Local Authority; and future plans after graduation. Eight care leavers agreed to take part in the study. Narrative accounts of academic and personal experiences were gathered through interviews using a critical incident approach (Tripp, 1993; Brookfield, 1987). Tripp (1993: 8) suggests that "critical incidents are produced by the way we look at a situation: a critical incident is the interpretation of the significance of an event”. Critical incidents can be either positive or negative - they are simply events which were considered important by participants. The critical incident approach has been rarely used in widening participation research, yet it provides a simple and appropriate method for encouraging students to reflect on specific concrete experiences. Students were asked questions to encourage them to recall specific incidents or events which had influenced them during their time at university:

1. What happened in the critical incident?

2. Did you receive any support at this time?

3. How has your thinking changed as a result of this event?

4. What do you do differently as a result of this event?

The 30-75 minute interviews took place in late spring and early summer 2013. Seven were face to face and the eighth was by telephone. Interviews were recorded with the students' permission, assuring respondents of anonymity. They were transcribed fully, and coded with the assistance of NVivo qualitative data analysis software to explore themes and 
relationships. The research team used the constant comparative method to draw out cross-cutting themes and patterns of response (Silverman, 2005), then tables were collated for each interview before comparing risk and protective factors within the group.

\section{The Sample}

All the interviewees were females aged between early 20s and early 40s. Three had children, ranging in age from 3 to 20 years. Seven were of white British origin and one was from a British Black African Caribbean background. There was a mix of students from the local area and those from other parts of the UK. They were studying a range of courses including social work, health and social care, law, criminology and business management. Six were first generation students (their parents had not participated in HE) though two of these had older siblings who had been to university. The students had spent varied amounts of time in care, ranging from one year to most of their childhood. Some involved more than one placement, or moving back and forth from care to birth family before coming to university. Although they were not specifically asked about their experiences in care, the students described care experiences which varied from very good to very poor, with one student revealing an attempted suicide during her time in care and another describing extreme abuse from carers during one of her placements. The reasons for coming into care were also not explicitly explored, though these were revealed to be factors such as domestic violence, alcoholism or mental health issues such as schizophrenia impacting on parenting. The students came from a range of educational backgrounds: some had successfully completed A' levels; others had entered via an Access course or Foundation degree. Some had been in paid employment before starting university; one had overcome drug addiction before starting.

It should be noted that this was a small sample of students at a single UK university, so generalisability of the findings cannot be assured, but the paucity of recent research covering the experience of care leaver students makes this a valuable early contribution to the debate.

\section{Findings}

The findings illustrate a range of risk and protective factors which impact on success for this group of students. Each individual had a specific set of factors, as indicated in table 1 for two students (pseudonyms are used throughout). These students have been selected to illustrate the differences within this group: Tania is typical of a student with lots of protective factors who performs well. Of greater concern, however, are students like Vivien who have a large number of risk factors and who typically achieve a 2.2 at best with considerable support. For a student like Vivien, the support of the care leaver service is particularly important. 
Table 1: Example of Protective and Risk Factors for two contrasting students

\begin{tabular}{|c|c|c|c|}
\hline & Protective Factors & Risk Factors & Outcomes \\
\hline Tania & $\begin{array}{ll}\text { - } & \text { Foster carers valued } \\
\text { - } & \text { Short time in care (1 } \\
\text { - } & \text { Gear) } \\
\text { attainment; } \\
\text { - } \quad \text { Enjoyed school } \\
\text { - } \\
\text { (grandended family } \\
\text { education } \\
\text { Birth father supportive } \\
\text { and lent money } \\
\text { Stable relationship } \\
\text { with supportive } \\
\text { partner } \\
\text { Saved money from } \\
\text { pre-university job } \\
\text { Motivation to support } \\
\text { children } \\
\text { Threw herself into } \\
\text { extracurricular } \\
\text { activities } \\
\end{array}$ & $\begin{array}{ll}- & \text { First generation } \\
\text { - } & \text { student } \\
\text { - } & \text { Fining responsibilities } \\
& \text { no Local Authority } \\
& \text { (LA) support }\end{array}$ & $\begin{array}{ll}\text { - } & \text { Achieved a First } \\
\text { - } & \text { Part-time post } \\
\text { teaching international } \\
\text { students } \\
\text { - } \quad \text { Enrolling for part-time } \\
\text { PhD }\end{array}$ \\
\hline Vivien & $\begin{array}{ll}\text { - } & \text { Motivation to } \\
\text { overcome care leaver } \\
\text { stereotypes and } \\
\text { stigma of being in } \\
\text { care } \\
\text { - Support of Care } \\
\text { Leaver Service }\end{array}$ & 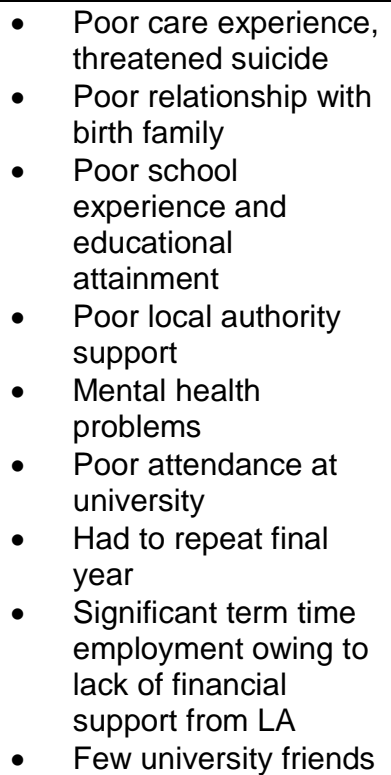 & $\begin{array}{l}\text { Didn't pass first time, } \\
\text { but re-sat some } \\
\text { assessments and } \\
\text { achieved a } 2.2 \text { with } \\
\text { additional work } \\
\text { - } \quad \text { No job lined up } \\
\text { Remains on } \\
\text { medication with } \\
\text { support from mental } \\
\text { health nurse } \\
\text { Threat of } \\
\text { homelessness }\end{array}$ \\
\hline
\end{tabular}

Based on the literature around resilience, the eight students' experiences were analysed in the light of their particular protective and risk factors and how these appeared to have affected their resilience through their HE experience and impacted on final results. Looking across the group of students, the key factors which emerge as important are:

- motivation for participation

- preparation for university 
- academic, personal and financial support at university

- the importance of a safety net such as the care leavers' service

These are discussed briefly in turn below, illustrated by examples from the interviews, after which a short final section outlines the students' accounts of the impact of being in care on their HE experience.

\section{Motivation for participation}

When asked why they had decided to come to university, reasons given were varied and included both intrinsic and extrinsic motivations: wanting to prove they were capable of it, wanting a specific career, encouragement from school or college staff, encouragement from foster carers or birth family such as grandparents. For one student, her foster care placement was pivotal:

'When I went into care I suppose I was academically naturally sort of capable I suppose you could say, but I didn’t really realise it and my head wasn't in a very good place. But going into care gave me the actual focus and they were very keen to get me to think about academic work as well ... so they turned it around for me really, you know they made me do my homework.' (Tania)

For another, the school environment was a key driver, and encouragement from a member of staff led to this student applying to university:

'I was at sixth form and everyone was applying for uni and it had never been like something that I'd ever thought of, and it wasn't until my head of sixth form, we got on really well, and she was you can go to uni, and I was like no I can't, how am I going to afford it, and she was like no you get loads of help ... and we worked out that all the help I get and stuff it was affordable, we then found something I was interested in, applied and came to uni.' (Wendy)

Some foster family siblings prompted the interest in university, suggesting that the aspirations and achievements of the whole foster family, teachers and peers (and not simply the educational background of the carers themselves) may be important in encouraging young people towards educational engagement. However, a motivation mentioned by one student was the desire to do better than her poorly educated foster carers suggesting that, although support from carers is important, the impact is not necessarily straightforward - with lack of awareness of education by the carers being a spur to effort and achievement in some cases.

Motivation for the choice of course was also interesting. In one case the choice of social work was based on a shocking care experience with relatives:

'I want to do social work 'cos when I lived with my aunt and uncle I had a social worker who would never see me [alone], would always see me in front of my aunt and uncle and ... at the time I didn't want 
to be seen with my aunt and uncle because obviously there were things that I wanted to disclose, I wasn't able to disclose. And so it continued and continued, and there wasn't really the opportunity to be seen alone ... and that's like one of the big reasons for me why I wanted to do it, 'cos I wanted to make sure that it's the children who are listened to rather than the adults.' (Anne)

Three students in total expressed these kind of altruistic motivations for undertaking their particular course, indicating that this was a key factor amongst these care leavers.

\section{Preparation for university}

Whilst most students felt their school or college had prepared them well for university (a protective factor), there was some concern that they had underemphasised the step-change of starting university. This was reflected in concerns upon arrival that the extent of independent learning required was greater than they had expected. Common student concerns about workload and personal finances were often intensified for these students which made it more difficult to prepare effectively for HE study:

'So money was the biggest concern in terms of how we were going to be able to afford our rent and look after the children, if they both had to go to nursery, how we'd be able to afford that, and that was really the worry for me.' (Tania)

One student recalled starting at university and being worried about being away from her family and being alone for the first time, as she had recently moved in with her grandparents after foster carers:

'I felt we'd just got together again, and then I was moving away ... It was sort of moving three hundred miles away from my family and being alone and not knowing anyone down here.' (Susan)

For this student, the start of university was another disturbance to an already disrupted childhood. During her first year, Susan was very homesick and returned to her hometown every other weekend; however, she gradually adapted to university life.

The students talked about university induction as an overwhelming time on first arrival they were showered with information and provided with social opportunities which were not always welcomed:

'I think it was enough information but it was all given to you too quickly in such a short space of time that everyone forgot it by the next week anyway so and then you're thinking where is this place, I know they told us but I can't remember.' (Diana)

Responses illustrated that the expectations about student desire for social activities in the first year of university were not always shared by this group: 
'To be honest with you ... I wasn't coming here to make friends, I was coming here because I had to come, you know just coming in for the lessons.' (Jenny)

However, others felt that the induction week had helped them settle in to University life through meeting other students as well as staff:

'Yeah, the bonds that you make; I was told that you make your best friends at university, I've made some good friends and I've probably got one very close friend from it.' (Julie)

One of the more surprising observations was that these students were in some ways very well prepared for university life, in that they had often experienced living more independently than young students arriving directly from the family home. Despite the common description of this group as 'looked after' young people, they were actually more accustomed to looking after themselves than most students, three noting their relative independence or reporting helping housemates with cooking and other household activities.

\section{Academic, personal and financial support for difficulties at university}

The students reported a variety of academic and personal difficulties over the duration of their studies, and response from university staff was crucial in ameliorating the impacts. It was clear that academic and personal issues frequently overlapped, so academic difficulties could be prompted by personal crises. For example, one student's mother was sectioned for schizophrenia during her first year. In taking some time away from university to be with her, she failed an assignment and had to undertake an additional task during the summer in order to progress. The cases where students gained support from academic tutors on both personal and academic issues were those with the most successful outcomes in such circumstances:

'I've actually really enjoyed my time here from start to finish, the course itself, the lecturers, all really supportive, you know it's a sort of open door policy, if you need anything you can drop them an email or go in and see them, which is a really nice support network.' (Tania)

However, the students noted substantial differences between staff responses to student concerns, with some refusing to offer any help outside of lecture times. Given the literature which identifies the importance of support from a significant adult in the lives of care leavers, academic and professional services staff support is crucial in ensuring positive outcomes for this group.

Some students needed additional support owing to health issues (one had almost six months off, yet still managed to pass with support from tutors) or financial difficulties. One student had undertaken as much as twenty hours 
per week paid work during her second year and (perhaps unsurprisingly) found it difficult to find time for study. Those students in paid employment felt they were less able to enjoy all aspects of university life because of the need to study when friends were enjoying other activities. Access to funding from their local authority varied enormously, and represented something akin to a 'postcode lottery' with some students having fees and accommodation costs paid, whilst others received next to nothing:

'Before I started university the whole way through they were promising that they paid for the fees, they paid for this, they paid for that, I wouldn't be in much debt ... And then when it comes down to it, I got nothing from them except for, they give me three train fares a year back home.' (Susan)

As Susan was quick to point out, the local authority was not providing what other students' parents would. Whilst there was a care leaver bursary available from the university, if students were not known to the care leavers' service, these funds could be difficult to allocate appropriately:

'When I found out about this care leavers' thing it was too late, and it annoys me a little bit that had I been more aware and I'd had the money, I wouldn't have had to work, so then I could have focused more on my studies and I probably could have got more involved with uni and my friends.' (Wendy)

Wendy went onto stress how hard it was to see her friends phone their parents when they were short of money, an option which was not open to her.

Again, links between personal and academic issues were very clear through several of the interviews. One student related the way in which undertaking her dissertation had taken its toll on her physically and mentally:

'It wasn't really until I was just getting my dissertation in that I spent three days in bed crying, it was kind of bringing up a lot of stuff in my past.' (Jenny)

\section{The importance of a 'safety net' such as a care leavers' service}

A key finding from this research was the importance for care leavers of the provision of a specific support service catering to their needs. For this group in particular, having a trusted point of contact in their lives was crucial. Where possible, the service made contact with new care leavers prior to their start at university, or on first arrival. The care leaver advice officer had been a great support for many students, and helped them navigate the sometimes labyrinthine university systems and processes:

'I tended to go to (the advice officer) a lot with finance stuff 'cos she seemed to know what I was meant to be doing and know the people, how to get through to them quicker than the students could.' (Diana) 
Another student had experienced support from the advice officer at a time of crisis - organising a grant for her to travel home and stay with family when she was contemplating withdrawing because of health problems:

'She's been very important, if it wasn't for her I don't think I'd still be here, I don't think I would have got my degree ... (the support officer) helped me get home for that week, and I think that week at home with my family showed me that I should be carrying on with my degree.' (Susan)

The officer had also intervened on another student's behalf on a number of occasions such as when she handed an assignment in late during a period of mental ill health, and when she had some possessions stolen whilst moving house. These students, and others, commented on the benefits of good communication, which included regular emails and updates as well as the ability to contact the advice officer on her mobile phone as well as in person in the office:

'She's sent me regular emails seeing how I am and she's always made me aware that if I need any support she's there, from day one ... she said 'I am here if you need anything' and that was nice to know. I do get on with it myself but it is nice to know that there is someone if it really gets too much.' (Julie)

For some students, the proactive support of the care leavers' service provided an essential life-line, since they were often loth to ask for help unprompted. The service provided social events and regular meetings for care leavers, although some students were not keen to engage because they were unwilling to talk about their care experiences:

'It was all just very weird because we went bowling and people like asking questions, it just wasn't what I wanted because they were all, so why were you in care ... which, it's all well if you want to discuss it but I thought it was just a night out.' (Anne)

Others found the meetings difficult to attend because of child care responsibilities, lectures or placements. However, those students who regularly attended the meetings were full of praise for them:

'I think it just helped because you had like a group of people who were going through exactly similar to you and obviously you could, if they knew something that could help you with say extra finance, they would be able to share it with everybody, so you learnt things off each other.' (Diana)

The students were keen to find help for essay writing and similar study issues, making the meetings which drew in other university services popular. It seems that although learning support is available through the main student services, the care leavers were more inclined to seek support through their known route. They were involved in setting the meeting agendas and contributing to the overall development of the meetings. This 
was an important context where their voices could be heard, and in which they could have some control over aspects of their HE experience.

\section{The impact of being in care}

Perhaps surprisingly, without exception, all the students felt that being in care had had a positive impact on their university experience although for varying reasons. For three students, their care experience influenced their desire to come to University to study a particular course such as Social Work, and they felt that they would be better able to empathise with clients in the future. Others felt that the experience of writing assignments which reflected on issues they had encountered personally had benefited their academic work:

'For me I've used a lot of my experience within my assignments because they like you to focus on stuff like that, however, when I write about it I don't feel like it's me I'm writing about, I am not that person anymore. She didn't leave me as such, but I was put into care, so she left me that's yeah. You know I can see neglectful parenting, you know maybe they weren't in the right place and I think this degree helps you to see both sides of the story.' (Julie)

The experience of writing was viewed as therapeutic in several cases, helping students make sense of and come to terms with their experiences:

'And through my dissertation, really looking and it's like going back to where the fabric was torn and with me it was about three or four years of age so I've just kind of come out of all that. I always felt I didn't quite own my place in the world, it's really hard to describe but I don't feel that anymore and I don't care so much what people think of me.' (Jenny)

Other students valued the independence that their care leaver status had given them. Comparing themselves to peers at university had made them aware of the life skills which they had unknowingly acquired at a young age. Finally, several students felt that their time in care had made them more determined to succeed for various reasons. These included proving themselves to be capable, and making a better life than their parents or carers:

'People always think people who've been in care are no good, you know, bad people, noisy. Yeah they've always got something to say about people that's been in care you know, and like most people say people that's been in care never achieve anything so I have proved myself and I proved them that you shouldn't judge a book by its cover, people are like that for a reason.' (Vivien)

All of the students in the study went on to complete their degrees successfully despite the challenges encountered. 


\section{Discussion and Conclusion}

The information provided by these care leavers provides a rich picture of their experiences of university life through the three years of study. The analysis gives depth to the findings of other research (e.g. Jackson et al., 2005; Stein, 2008; Driscoll, 2013; Hyde-Dryden, 2012, Munson, 2013) about the factors which enhance care leavers' access to HE, including high intrinsic motivation, encouragement from teachers and family, and the support of the Local Authority. They also offer a more detailed view of the potential protective factors that can lead to resilience and therefore subsequent retention and success at university level. To reach higher education for care leavers is a significant achievement in itself, and these students undoubtedly display a number of characteristics which make them more likely to achieve their goals. Half of the students had considered withdrawal when their difficulties were very profound but all had persevered, suggesting a strong resilience within this group. The analysis of risk and protective factors indicates the importance of ensuring support while they are at university, as this may 'tip the balance' between the two, and help them demonstrate the resilience required for successful completion.

There is increasing evidence that care leavers have specific academic, personal and financial support needs which universities can assist with. Whilst financial incentives have rarely been demonstrated to impact upon students' decisions to participate in HE (Corver, 2010), they may make withdrawal less likely and they certainly ease the transition for students from non-traditional groups, making the full university experience more accessible. Moreover, personal and academic support can make a huge difference in care leaver students' persistence. In the context of the fees and maintenance costs incurred by UK students, it is even more important that these students have opportunities to succeed in their studies, especially given the impact of educational qualifications on future life chances for care leavers (Jackson and Martin 1998).

In terms of support for care leavers in HE, Jackson et al.'s research in 2005 reported little targeted provision and limits on even the most basic student support:

Participants with problems did not get appropriate help from Student Support Services in their institution and many had no contact with personal tutors. (p. 10)

However, our research suggests that this does not have to be the case, and that specialist provision can provide a lifeline for students at risk. It is not clear from our study how widespread such provision is, although it was certainly unusual in 2005:

Most HEIs now have officers in post with a widening participation remit. However, very few of those who responded to the questionnaire 
had any special provision in place for applicants or students with a care background. (p. 11)

Arguably, there has been a change in the university culture regarding student support since that research was undertaken. There are certainly a large number of institutions with the Buttle Trust (2013) Quality mark indicating that they have a 'robust strategy in place to support students from a care background'.

It is particularly important that universities review the support which they provide for care leavers given the evidence here that Local Authority 'corporate parenting' is frequently lacking, with support being haphazard in most cases. The widely-used term, 'corporate parent' is used to describe the responsibility of the local authority to promote the best interests of the child or young adult. Our research raises the question of whether universities can take on the role of corporate parent, and what is required in order to conduct this role effectively. Jackson et al. (2005) note that students without supportive foster parents can feel very isolated in the early weeks of university, and our study indicated the importance of the care leaver advice officer in supporting students during this time. The advice officer took on something akin to the role of 'parent' for some of these students, offering psychological support, co-ordination with other services, and sometimes intervening on a students' behalf - echoing the ways in which birth parents support their own children. It is notable that for some students, the care leavers' service is one of the few protective factors which they have (see table 1). It provides an essential safety net for the most 'at risk' students, and enables them to continue with their education. Although it is arguable whether a university should be responsible for providing this kind of support for students, existing corporate parenting of children in care (and beyond) is often deficient and contributes to poor educational outcomes. Research on school-age children in care indicates that teachers were generally seen as assisting educational progress whereas social workers were more often seen as hindering it (Harker et al., 2003). This suggests that support which is embedded in the educational institution may be more effective.

In addition to the direct support role, the care leaver service also offered opportunities for social interaction and support from peers. This may enhance the integration into HE experienced by these students, which has been identified as an important factor in retention. Tinto (1993) identifies aspects of the academic environment (including interaction with staff), and social system (such as extra-curricular activities and peer group integration) as playing a key role in the student experience. He concludes that students who are less well integrated into the academic and social settings are more likely to withdraw from study. This is not to ascribe to an 'integrationist viewpoint' - whereby the responsibility for student withdrawal is placed in the hands of students themselves:

requiring the student to assimilate to the institution and the ways of studying within that institution, rather than any institutional transformation (Rose-Adams, 2013: 97) 
Rather, Tinto's model is viewed in this context as providing a guide for universities about the issues which are of importance in making students feel part of the institution. In the current climate, where increasing focus is placed on the student voice, it is even more important that vulnerable students are given opportunities to be heard:

Having a voice partly depends on someone hearing that voice with understanding, and coaching it forth. Certain qualities in listening, and listeners, increase the chances of recovering vulnerable student voices. (Batchelor, 2006: 799)

Arguably, the care leavers' service in this study provided a unique context where the voices of this marginalised group were heard.

The success of the care leaver students in this and other studies - despite their difficult childhood experiences - provides a counter to the narrative, epitomised by Gorard et al. (2006) that the influence of early life experiences is so overwhelmingly powerful as a predictor of educational success that university efforts at enhancing access are doomed to failure. Whilst it is clear that early intervention is crucial in influencing the educational aspirations and success of care leavers - as with other widening participation groups (see Hart, 2010) - the actions of universities and their academic and support staff can have significant impacts on care leavers' success in HE. However, in order to provide a HE experience which is transformative, which does not simply reproduce the 'social status quo' (Bourdieu and Passeron, 1990), institutions need to make special provision for those students for whom entering university is simply the next stage in an ongoing battle against the odds.

\section{Acknowledgements}

We would like to acknowledge the support of the Care Leaver Service at Plymouth University, expressing particular thanks to Louise Baker and Nadine Johns who commissioned this research. We are also extremely grateful to all participants who gave up their time to talk so openly to us about their experiences. All views expressed in this report, and any errors or omissions, remain the responsibility of the authors.

\section{References}

Batchelor, D. C. (2006) 'Vulnerable Voices: An examination of the concept of vulnerability in relation to student voice', Educational Philosophy and Theory, 38: 787-800.

Berridge, D. (2007) 'Theory and explanation in child welfare: education and looked-after children’, Child \& Family Social Work, 12, 1: 1-10.

Berridge, D. (2012) 'Educating Young People in Care: What have we learned?' Children and Youth Services Review 34, 6: 1171-1175. 
Bourdieu, P., and Passeron, J. (1990) Reproduction in Education, Society and Culture, London: SAGE.

Brookfield, S. (1987) Developing Critical Thinkers, Buckingham: OU press.

Buttle (2013) Buttle UK Quality Mark Criteria. Available at: http://www.buttleuk.org/pages/quality-mark-criteria.html (accessed 4/ 12/13).

Cashmore, J., Paxman, M. and Townsend, M. (2007) 'The educational outcomes of young people 4-5 years after leaving care: An Australian perspective’, Adoption and Fostering 31, 1: 50-61.

Cheung, Y. and Heath, A. (1994) 'After care: the education and occupation of adults who have been in care’, Oxford Review of Education 20: 361-374.

Corver, M. (2010) Have Bursaries Influenced Choices Between Universities? A report to OFFA. http://www.offa.org.uk/wp-content/uploads/2010/09/Havebursaries-influenced-choices-between-universities-.pdf (Accessed 18/11/13).

DfE (2012) Outcomes for Children Looked After by Local Authorities in England: as at 31March 2012, Statistical First Release, SFR32/2012, London: DfE, December 2012.

Dixon, J., Wade, J., Byford, S., Weatherly, H. and Lee, J. (2006) Young People Leaving Care: A Study of Costs and Outcomes, York: The University of York.

Driscoll, J. (2011) 'Making Up Lost Ground: Challenges in supporting the educational attainment of looked after children beyond Key Stage 4', Adoption and Fostering 35, 2: 18-33.

Driscoll, J. (2013) 'Supporting Care Leavers to Fulfil their Educational Aspirations: Resilience, Relationships and Resistance to Help', Children and Society, 27: 139-149.

Gorard, S., Smith, E., May, H., Thomas, L., Adnett, N. and Slack, K. (2006) Review of widening participation research: addressing the barriers to participation in higher education, Bristol: HEFCE.

Harker, R. M., Dobel-Ober, D., Lawrence, J., Berridge, D. and Sinclair, R. (2003) 'Who Takes Care of Education? Looked after children's perceptions of support for educational progress', Child \& Family Social Work, 8: 89-100.

Hart, M. (2010) '2010: a turning point in widening participation?' Widening Participation and Lifelong Learning 12: 74-77.

Hyde-Dryden, G. (2012) Overcoming by degrees: exploring care leavers' experiences of higher education in England, A Doctoral Thesis. Loughborough University, March 2012.

Jackson, S. and Martin, P. (1998) 'Surviving the Care System: education and resilience', Journal of Adolescence 21: 569-583.

Jackson, S., Ajayi, S. and Quigley, M. (2005) Going to University from Care. Institute of Education, University of London.

Jackson, S. and Simon, A. (2006) The Costs and benefits of Educating Children in Care. In Chase, E., Simon, A and Jackson, S. (Eds) (2006) In Care and After: A Positive Perspective, Oxford: Routledge. 
Mishler, E.G. (1986) Research Interviewing: Context and Narrative, Cambridge: Harvard University Press.

Munson, R.E. (2013) From Care to University: How Protective Factors and the Development of Resilience can Contribute to the Successful Educational Outcomes of Care Leavers, unpublished research report, University of Bath.

Rose-Adams, J. (2013) 'Leaving university early: Exploring relationships between institution type and student withdrawal and implications for social mobility', Journal of Widening Participation and Life Long Learning 15, 2: 96-112.

Silverman, D. (2005) Doing qualitative research (2nd edition), London: Sage Publications.

Stein, M. (2006) 'Research Review: Young people leaving care', Child and Family Social Work 11, 3: 273-279.

Stein, M. (2008) 'Resilience and Young People Leaving Care', Child Care in Practice 14, 1: 35-44.

Tinto, V. (1993.) Leaving college: Rethinking the causes and cures of student attrition (2nd ed.), Chicago: University of Chicago Press.

Tripp, D. (1993) Critical Incidents in Teaching, London and New York: Routledge

Welbourne, P. and Leeson, C. (2012) 'The Education of Children in Care: a research review', Journal of Children's Services 7, 2: 128-143. 